\title{
PROSPEK PEMANFAATAN METABOLIT SEKUNDER TUMBUHAN SEBAGAI PESTISIDA NABATI UNTUK PENGENDALIAN PATOGEN PADA TANAMAN KARET
}

\author{
The Prospect of Plant Secondary Metabolite as Botanical PesticideAgainst Pathogens on Rubber
}

Cici Indriani Dalimunthe dan Arief Rachmawan

Balai Penelitian Sungei Putih, PO. Box. 1415 Medan 20001

Email: cc_dalimunthe@yahoo.com

Diterima 19 Januari 2017 / Direvisi 23 januari 2017 / Disetujui 17 April 2017

\begin{abstract}
Abstrak
Penyakit tanaman akan terus menjadi faktor pembatas tercapainya produksi pertanian yang optimal. Hal ini menuntut para fitopatologis terus melakukan riset untuk mencari berbagai taktik pengendaliannya. Pestisida sintetis sebaiknya tidak menjadi pengendali utama karena banyaknya efek negatif. Pemanfaatan pestisida nabati menjadi alternatif dalam pengendalian penyakit. Pestisida nabati memiliki keunggulan diantaranya ramah lingkungan, mudah terdegradasi, sumber daya lokal melimpah,murah, serta sejalan dengan konsep pertanian berkelanjutan. Artikel ini memberikan informasi mengenai jenis metabolit sekunder tanaman dan jalur pembentukannya, serta prospek pemanfaatan metabolit tersebut sebagai pestisida nabati untuk mengendalikan penyakit pada tanaman karet. Besarnya keanekaragaman hayati tumbuhan menghasilkan aneka jenis metabolit sekunder yang berpotensi sebagai pestisida nabati. Total ratusan ribu jenis tumbuhan yang sudah dikenal memiliki efek medisinal, banyak yang diteliti dan dimanfaatkan sebagai pestisida nabati. Produk pestisida nabati untuk tanaman hortikultura mulai banyak dikomersialkan. Pada tanaman karet, pemanfaatan pestisida nabati masih pada tahap penelitian,dan belum sampai tahap formulasi produk komersial. Oleh karena itu diperlukan langkah strategis dan arah yang jelas terkait penelitian pestisida nabati pada tanaman karet diantaranya berupa eksplorasi dan
\end{abstract}

pendataan pestisida nabati potensial, isolasi dan pemurnian bahan aktif pestisida nabati serta studi mekanisme kerja pestisida nabati.

Kata kunci: pestisida nabati, metabolit sekunder, penyakit karet

\section{Abstract}

Plant diseases will be a limiting factor to achieve optimum agricultural production. This requires pathologists to continue to do research in finding various disease controlstrategies. The use of synthetic pesticideis better not to be the main control of diseases because of the negative effects. Utilization of botanical pesticide isan alternative of disease control. Several advantages of botanical pesticides are environmentally friendly, easily degraded, local resources abundant, relatively cheap, and in line with the concept of sustainable agriculture. This article provides informationon the type and the metabolic pathway of plant secondary metabolites, as well as its prospect as botanical pesticides to control disease in rubber plant. The magnitude plant biodiversity produces various types of secondary metabolites that have the potential as botanical pesticides. Totally the hundreds of thousands of plants have been known to have medicinal effects, lot of them has been widely studied and used as plant pesticides. Botanical pesticide products for horticulture crops have begun to commercial. In rubber plantation, utilization of botanical pestice is still at the research stage, and had not yet reached the stage of commercial product formulation. Therefore we need a strategic step and a clear related of research related to botanical pesticide in rubber plantation 
such as data collection, exploration, isolation and purification of secondary metabolites, as well as study the mechanism of action of the secondary metabolites to control rubber plant disease.

Keywords: botanical pesticide, secondary metabolites, rubber plant diseases

\section{Pendahuluan}

Ekstrak tanaman telah digunakan selama berabad-abad sebagai obat tradisional, bahan pengawet hasil pertanian, pengusir hama, minyak wangi serta rempah-rempah. Beberapa contoh ekstrak tanaman yang telah digunakan adalah lavender dan citronella sebagai repellent (Geetha dan Roy, 2014; Kongkaewet al., 2011), rape seed oil dan quassia sebagai pestisida (EFSA, 2013; Psota et al., 2010), laminarindan lecithinesebagai fungisida (Yoon et al., 2013; EFSA, 2014), pine oil sebagai herbisida serta caraway seed oil sebagai penghambat pertumbuhan(Isman, 2006). Dari beberapa contoh penggunaan ekstrak tanaman tersebut, kelompok senyawa dalam ekstrak tanaman yang sering digunakan adalah pyrethrum, neem, rotenon dan minyak atsiri. Ekstrak tanaman lainnya yang banyak dimanfaatkan sebagai pestisida dalam pertanian organikdiantaranya adalah ekstrak dari tanaman daun sirih, cengkeh, serai, srikaya, akar tuba, nimba dan jambu mete (Syakir, 2011). Pada hakikatnya, ekstrak tanaman merupakan kumpulan metabolit sekunder dengan jenis, kadar dan fungsi yang berbeda-beda sesuai kebutuhan dan kondisi tanaman.

Tanaman mampu mensintesis berbagai metabolit sekunder dengan struktur dan kerangka karbon yang kompleks dan unik. Metabolit sekunder tersebut merupakan salah satu sumber keanekaragaman struktur kimia dan aktivitas biologi. Sekitar $14-28 \%$ ekstrak tanaman tingkat tinggi digunakan sebagai obat-obatan, dan $74 \%$ diantaranya diketahui mempunyai fungsi medisinal setelah melalui proses etnomedik atau penggunaan sebagai obat tradisional (Cavoski, et al., 2011). Tanaman dan metabolit sekundernya juga merupakan sumber penting untuk memperoleh pestisida nabati dan produk turunan pestisida nabati. Perhatian terhadap metabolit sekunder sebagai pestisida nabati telah banyak mengalami peningkatan seiring dengan adanya resistensi hama penyakit, serta resiko keracunan dan kerusakan lingkungan akibat pestisida buatan. Eksplorasi produk metabolit sekunder sebagai bahan pengendali hama penyakit menunjukkan peningkatan karena bersifat non fitotoksik dan mudah terdegradasi (Syakir, 2011; Cavoski, et al., 2011).

Saat ini pestisida nabati banyak dikembangkan dan mendapatkan perhatian sebagai salah satu usaha ke arah pengembangan teknologi pertanian alternatif. Banyak bagian tanaman yang mempunyai potensi sebagai pestisida nabati yaitu akar, batang, daun dan bunga. Limbah pertanian, misalnya limbah pabrik rokok dan jamu, juga dapat dimanfaatkan sebagai pestisida nabati. Dengan kekayaan plasma nutfah Indonesia, tidak mustahil apabila ada diantaranya yang mengandung metabolit sekunder yang dapat mengatasi penyakit tanaman karet. Prospek penelitian dan pengembangan metabolit sekunder untuk penyakit tanaman karet sangat terbuka.

Tulisan ini memberikan informasi mengenai jenis metabolit sekunder tanaman dan jalur pembentukannya, serta prospek pemanfaatan metabolit tersebut sebagai pestisida nabati untuk mengendalikan penyakit pada tanaman karet. Informasi yang disajikan diharapkan dapat menjadi informasi tambahan untuk melakukan penelitian mengenai metabolit sekunder khususnya terkait pengendalian penyakit pada tanaman karet. Melalui penelitian tersebut diharapkan muncul formula alternatif pestisida nabati yang murah dan ramah lingkungan. 


\section{Metabolit Sekunder}

Semua organisme perlu mentransformasi dan mengubah senyawa organik menjadi bahan makanan agar dapat bertahan hidup, berkembang dan bereproduksi. Senyawa organik dijadikan bahan dasar untuk menyusun jaringan dan juga menghasilkan energi berupa ATP. Senyawa organik diolah dalam tubuh organisme melalui reaksi kimia yang kompleks dengan bantuan enzim. Setiap organisme mempunyai kemampuan yang berbeda dalam transformasi senyawa organik. Tanaman mempunyai kemampuan untuk mensintesis senyawa organik dari senyawa anorganik melalui proses fotosintesis, sedangkan hewan dan mikroorganisme tidak memiliki kemampuan tersebut. Mereka memperoleh senyawa organik dari asupan makanan. Proses pengolahan senyawa organik dalam tubuh organisme dinamakan metabolisme, sedangkan tahapan dan jalur yang terlibat disebut dengan jalur metabolisme(Dewick, 2009).

Secara umum, ada dua macam metabolisme, yaitu metabolisme primer dan metabolisme sekunder. Metabolisme primer menghasilkan metabolit primer, sedangkan metabolisme sekunder menghasilkan metabolit sekunder. Metabolisme primer terdapat dalam semua organisme dengan proses dan jalur yang hampir sama, sedangkan metabolisme sekunder mempunyai jalur dan produk yang spesifik dan unik untuk setiap organisme. Metabolisme primer terlibat secara langsung dalam pertumbuhan, sedangkan metabolisme sekunder umumnya tidak terlibat dalam aktivitas pertumbuhan (Anurag et al., 2015). Metabolisme primer memodifikasi dan mensintesis karbohidrat, lemak, protein dan asam nukleat, sedangkan metabolisme sekunder menghasilkan metabolit sekunder dengan ukuran relatif kecil, umumnya dengan bobot molekul kurang dari $3000 \mathrm{Da}$ (Dewick, 2009). Metabolit primer berperan dalam proses fotosintesis dan respirasi, sedangkan metabolit sekunder lebih berperan dalam fungsi pertahanan tanaman (Anurag et al., 2015).

Metabolit sekunder dihasilkan pada tingkat pertumbuhan atau kondisi tertentu. Kelompok senyawa ini diproduksi dalam jumlah terbatas, tidak terus-menerus dan hanya untuk tujuan spesifik. Adanya kemampuan tanaman untuk melakukan fotosintesis menyebabkan produk metabolit sekunder yang dihasilkan tanaman sangat berbeda dari metabolit sekunder yang dihasilkan organisme lainnya. Pada tanaman, senyawa metabolit sekunder memiliki beberapa fungsi, diantaranya sebagai atraktan (menarik organisme lain), pertahanan terhadap patogen, perlindungan dan adaptasi terhadap stress lingkungan, pelindung terhadap sinar ultra violet, sebagai zat pengatur tumbuh dan untuk bersaing dengan tanaman lain (alelopati). Metabolit sekunder juga diduga sebagai limbah atau produk detoksifikasi tanaman, namun sebagian besar fungsi metabolit sekunder masih belum diketahui (Dewick, 2009; Kabera et al., 2014). Penelitian terhadap metabolit sekunder masih merupakan salah satu area penelitian terbesar guna menentukan fungsi dan sifat farmakologi dari masing-masing metabolit sekunder (Kabera et al., 2014).

Dari sudut pandang kimia, metabolit sekunder sangat menarik untuk dipelajari dengan berbagai alasan, antara lain sifat yang unik, keragaman struktur kimia, serta potensi sebagai kandidat obat dan pestisida alami (Cavoski et al., 2011). Metabolit sekunder mempunyai sifat unik dan spesifik karena dihasilkan dalam jumlah terbatas dan dengan struktur yang berbeda. Keragaman struktur kimia metabolit sekunder sangat berlimpah, bahkan banyak diantaranya mempunyai susunan yang sangat kompleks sehingga relatif sulit untuk disintesis di laboratorium. Penggunaan metabolit sekunder diantaranya adalah sebagai bahan obat, bahan kimia pertanian, makanan tambahan serta bahan kosmetik. Beberapa contoh metabolit sekunder yang telah komersial dan banyak dikenal adalah penisilin, morfin (Dewick, 2009), shikonin (anti bakteri), ginsenoida 
(penambah vitalitas), vinblastin vincristine (obat leukimia) dan ajmalisin (anti hipertensi) (Mariska, 2013).

\section{Jalur Pembentukan Metabolit Sekunder} sekunder berasal dari metabolisme primer, dan secara garis besar terbagi menjadi empat yaitu asetil koenzim A, asam sikimat, asam mevalonat dan metileritritol fosfat (Dewick, 2009; Kabera et al., 2014). Berdasarkan bahan dasar tersebut kemudian dikenal adanya jalur asetat malonat, jalur sikimat, jalur mevalonat dan jalur metileritritol fosfat. Aneka jenis senyawa metabolit sekunder disintesis dari salah satu atau kombinasi dari bahan dasar penyusun tersebut.
Bahan dasar penyusun senyawa metabolit

\section{Jalur asetat malonat}

Jalur asetat malonat dibentuk dari bahan dasar asetil koenzim A, yang tersusun dari 2 atom karbon. Asetil koenzim A bereaksi melalui reaksi kondensasi membentuk unitunit yang lebih besar dengan jumlah atom karbon kelipatan 2, yang disebut poli-betaketo atau poliketida (Gambar 1) (Dewick, 2009). Metabolit sekunder yang termasuk dalam jalur ini adalah asam lemak (laurat, miristat, palmitat, stearat, oleat, linoleat, linolenic), poliasetilen, prostaglandin, macrolide dan senyawa-senyawa aromatik (antraquinon dan tetrasiklin). Tanaman yang menghasilkan senyawa ini antara lain: Jarak pagar, kelapa sawit, kelapa, jagung, kacang tanah, zaitun, bunga matahari, kedelai, wijen, kapas, coklat, dan alpukat (Mariska, 2013).

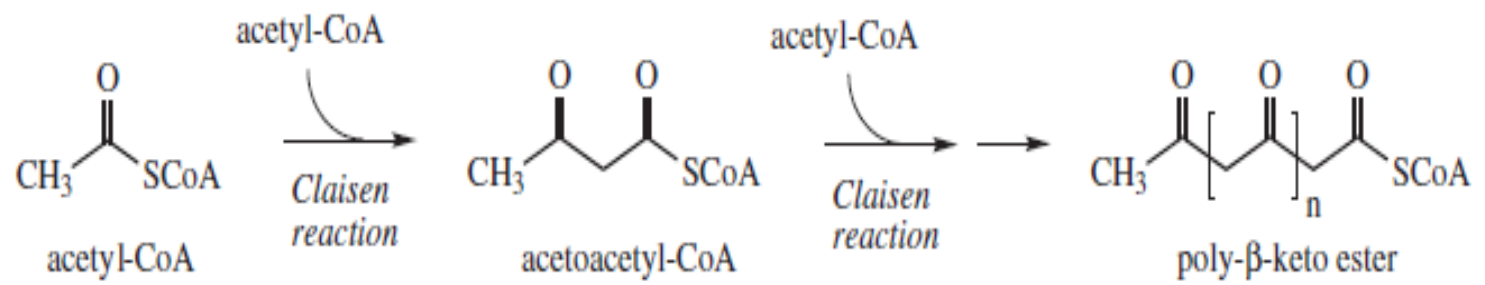

Gambar 1. Jalur pembentukan asetat melonat Sumber : (Dewick, 2009)

\section{Jalur shikimat}

Jalur metabolisme ini hanya terdapat pada mikroorganisme dan tanaman, sedangkan hewan tidak memiliki jalur ini (Herrmann \& Weaver, 1999). Senyawa intermediat utama dari jalur ini adalah asam shikimat, suatu senyawa yang pertama kali diisolasi dari tanaman Illicium $s p$. Jalur shikimat merupakan jalur alternatif pembentukan senyawa aromatik khususnya asam amino aromatik L-fenilalanin, L-tirosin dan Ltriptofan (Gambar 2) (Gleason and Chollet, 2012). L-fenilalanin dan L-tirosin merupakan unit pembangun dari senyawa-senyawa kelompok fenilpropan dan poliketida aromatik (termasuk flavonoid). Bersama Ltriptofan, kedua asam amino tersebut juga merupakan unit pembangun dari kelompok senyawa alkaloid. 


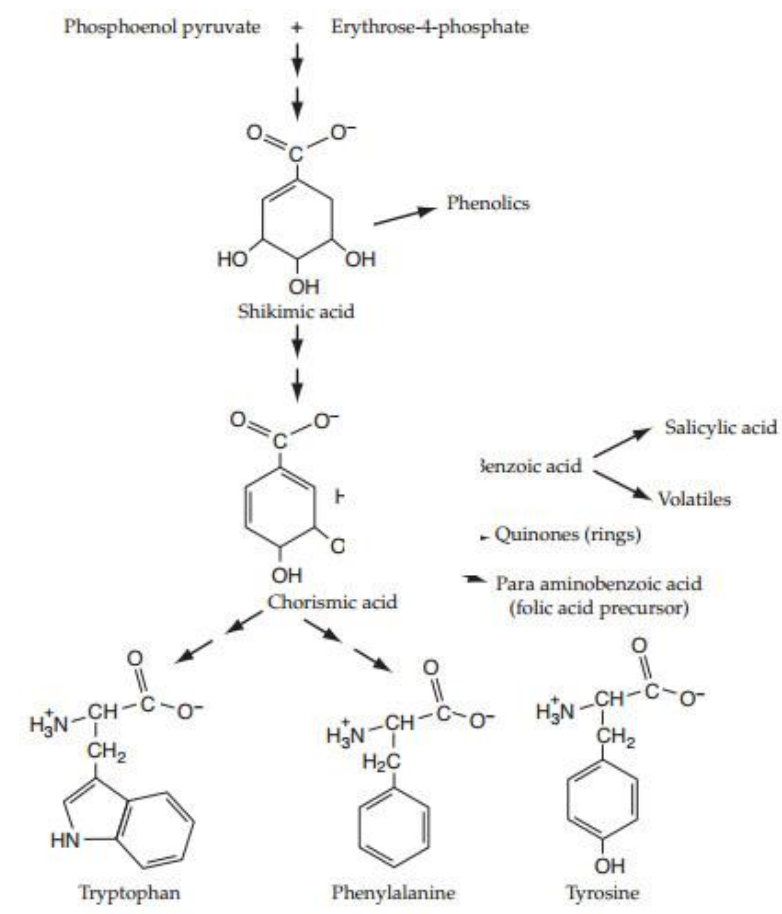

Gambar 2. Jalur pembentukan asam shikimat dari eritrosa Sumber : (Gleason and Chollet, 2012)

Alkaloid adalah suatu golongan senyawa organik yang terbanyak ditemukan di alam. Alkaloid dapat ditemukan dalam berbagai bagian tumbuhan antara lain biji, daun, ranting dan kulit kayu. Hampir semua alkaloid yang ditemukan di alam mempunyai keaktifan fisiologis tertentu.Ada yang bersifat racun tetapi ada juga yang sangat berguna sebagai obat (Ting et al., 2014; Lee et al., 2014).Kuinin, morfin dan striknin adalah alkaloid yang terkenal dan mempunyai efek fisiologis dan psikologis. Semua alkaloid mengandung paling sedikit sebuah atom nitrogen yang biasanya bersifat basa. Alkaloid berasal dari beberapa asam amino yang dibedakan atas alkaloid alilsiklik berasal dari asam amino ornitin dan lisin, alkaloid aromatik berasal dari fenilalanin dan tiroksin, dan alkaloid aromatik jenis indol berasal dari triptofan.

Flavanoid adalah kelompok senyawa polifenolik dalam tanaman yang biasa ditemukan pada sayuran, buah, bunga, biji, mapun madu dan propolis (Ahmadet al., 2015). Kelompok ini merupakan jenis fenolik terbesar yang ditemukan di alam, yang terbentuk melalui jalur shikimat. Flavonoid Senyawa-senyawa ini merupakan zat warna merah, ungu, dan biru, dan sebagian zat warna kuning yang ditemukan dalam tumbuh-tumbuhan. Flavanoid mempunyai kerangka dasar karbon yang terdiri dari 15 atom karbon. Di mana dua cincin benzen $\left(\mathrm{C}_{6}\right)$ terikat pada suatu rantai propan $\left(\mathrm{C}_{3}\right)$ sehingga membentuk suatu susunan $\mathrm{C}_{6}-\mathrm{C}_{3^{-}}$ $\mathrm{C}_{6}$. Susunan ini dapat menghasilkan tiga jenis struktur, yakni 1,3-diarilpropan atau flavonoid, 1,2-diarilpropan atau isoflavonoid, dan 1,1-diarilpropan atau neoflavonoid(Dewick, 2009). Senyawasenyawa flavonoid yang biasanya ditemukan di alam yaitu flavon, flavanol dan antosianidin. Senyawa isoflavonoid yaitu isoflavon, rotenoid dan kumestan, sedangkan neoflavonoid meliputi jenis-jenis 4arilkumarin dan berbagai dalbergoin.

\section{Jalur mevalonat dan metileritritol fosfat}

Jalur mevalonat dan metileritritol fosfat (non-mevalonat) merupakan jalur pembentuk 
kelompok senyawa terpenoid dan steroid (Dewick, 2009). Jalur mevalonat terjadi di sitosol dan mitokondria, sedangkan jalur metileritritol fosfat terjadi di plastida. Pada jalur mevalonat, prekursol awalnya adalah asetil Co-A, sedangkan pada jalur metileritritol fosfat, prekursor awal berupa piruvat dan gliseraldehid-3-fosfat (Nes \& Zhou, 2001). Kedua jalur tersebut akan membentuk isopentenil pirofosfat (IPP) dan dimetilalil pirofosfat (DMAPP) yang merupakan prekursor universal pembentukan rantai lima karbon, $\mathrm{C}_{5}$.

Terpenoid merupakan kelompok terbesar dari semua metabolit (Bohlmann \& Keeling, 2008). Terpenoid tersusun dari rangkaian unit isopren (rantai lima karbon) yang terhubung melalui ikatan kepala ke ekor. Terpenoid diklasifikasikan menjadi hemiterpen $\left(\mathrm{C}_{5}\right)$, monoterpen $\left(\mathrm{C}_{10}\right)$, sesquiterpen $\left(C_{15}\right)$, diterpen $\left(C_{20}\right)$, sesterterpen $\left(C_{25}\right)$, triterpen $\left(C_{30}\right)$, dan tetraterpen $\left(C_{40}\right)$.
Contoh senyawa dan struktur dari kelompok terpenoid disajikan pada Gambar 3 (Dewick, 2009). Terpenoid yang ditemukan di alam sebagian besar merupakan komponen minyak atsiri. Kelompok senyawa minyak atsiri dianggap mempunyai efek kuratif dalam pengobatan alternatif (Kabera et al., 2014). Terpenoid adalah kelompok senyawa yang memberikan rasa, bau, dan warna pada tumbuhan. Terpenoid biasanya terdapat pada daun dan buah tanaman tingkat tinggi misalnya pada tanaman pinus dan sitrus. Hasil penyulingan terfraksi dari minyak atsiri terdiri dari senyawa-senyawa golongan terpenoid yang mengandung 10 atom atau 15 atom karbon. Bahan-bahan alam lainnya selain minyak atsiri mengandung pula terpenoid dengan 20, 30 dan 40 atom karbon.Senyawa terpenoid yang sangat familiar dalam kehidupan sehari-hari adalah karet alam (cis 1,4 poliisopren).

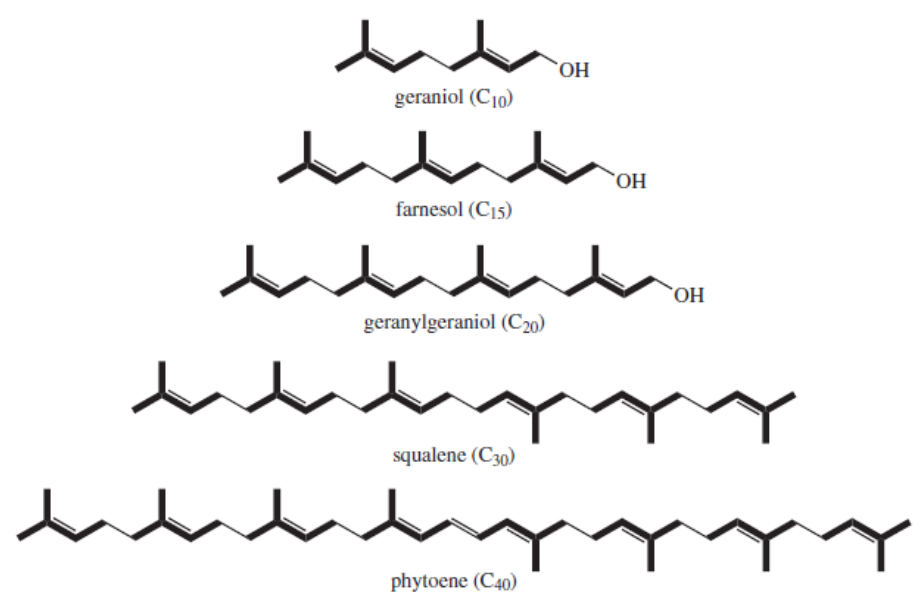

Gambar 3. Contoh senyawa dan struktur dari kelompok terpenoid Sumber : (Dewick, 2009)

\section{Produk Pestisida Nabati}

Berdasarkan sumber bahan aktifnya, pestisida dikelompokkan ke dalam pestisida hayati, nabati dan sintetis. Disebut pestisida hayati jika bahan aktifnya adalah organisme hidup, antara lain serangga predator, nematoda entomopatogen, mikroorganisme antagonis dan hasil fermentasi bahan alami.
Disebut pestisida nabati jika bahan aktifnya berasal dari tumbuhan, dan jika bahan aktifnya dari senyawa kimia sintetis maka disebut pestisida sintetis (Supriadi, 2013).

Syakir (2011) mencatat bahwa hanya ada 22 pestisida nabati yang telah terdaftar atau kurang $1 \%$ dari jumlah pestisida yang terdaftar yaitu 2.067 merek pestisida di Kementerian Pertanian Indonesia.Jumlah 
pestisida terdaftar tersebut meningkat dari tahun ke tahun. Berdasarkan buku "Pestisida untuk Pertanian dan Kehutanan Tahun 2014", ada sebanyak 3.005 merek pestisida telah terdaftar dan atau telah mendapat izin Menteri Pertanian (Ditjen PSP, 2014). Pestisida kimia yang bersifat instan, dan dengan banyak pilihan tersebut cenderung lebih dipilih oleh para petani. Namun, dengan semakin berkembangnya pemahaman terhadap kelestarian lingkungan, maka kebijakan penggunaan pestisida alternatif menjadi suatu yang terus diupayakan. Kebijakan penelitian yang mendukung pengembangan pestisida nabati sebagai alternatif juga lebih menjadi prioritas dibandingkan pestisida kimia.

Pestisida nabati merupakan bahan aktif tunggal atau majemuk yang berasal dari tumbuhan yang bisa digunakan untuk mengendalikan organisme pengganggu tumbuhan. Pestisida nabati ini bisa berfungsi sebagai penolak, penarik, antifertilitas (pemandul), pembunuh, dan bentuk lainnya. Secara umum, pestisida nabati diartikan sebagai suatu pestisida yang bahan dasarnya dari tumbuhan yang relatif mudah dibuat dengan kemampuan dan pengetahuan terbatas. Karena terbuat dari bahan alami atau nabati, maka jenis pestisida ini bersifat mudah terurai (bio-degradable) di alam, sehingga tak mencemari lingkungan dan relatif aman bagi manusia dan ternak peliharaan (Syakir, 2011).Di Indonesia terdapat banyak jenis tumbuhan dan plasma nutfah penghasil metabolit sekunder yang dapat dimanfaatkan sebagai pestisida nabati. Beberapa contoh tanaman yang telah diteliti sebagai pestisida nabati adalah serai, sirsak, kemangi, selasih, gadung, daun sembung, pinang, cengkeh dan nimba. Bahkan, beberapa produk pestisida nabati telah terbukti efektif untuk mengendalikan OPT pada beberapa komoditas perkebunan, pangan dan hortikultura (Tabel 1).

Banyak pestisida yang dapat digunakan secara bersamaan atau bergiliran karena bersifat kompatibel satu sama lain. Beberapa contohnya adalah Trichoderma kompatibel dengan jenis pestisida sintetis (mankozeb, kaptan, deltametrin, monokrotofos dan imidaklorid). Asap cair bersifat sinergis dengan karbofuran sehingga menghemat penggunaan karbofuran sampai $50 \%$ dalam pengendalian wereng coklat. Beauveria bassiana dan Metharizium anisopliae kompatibel dengan ekstrak mimba dan spinosad (Supriadi, 2013). 
Tabel 1. Beberapa contoh produk pestisida nabati hasil riset yang telah diformulasi menjadi produk komersial di Indonesia

\begin{tabular}{|c|c|c|c|}
\hline No & Nama produk & Bahan aktif & OPT target \\
\hline 1 & Bio Protektor 1 & $\begin{array}{l}\text { Eugenol, Sitronelal, } \\
\text { Geraniol, Xanthorrhizol }\end{array}$ & $\begin{array}{l}\text { Keong mas pada padi; Wereng coklat } \\
\text { pada padi; Croccidolomia sp pada kubis; } \\
\text { kutu } A \text {. hartii pada rimpang jahe; } \\
\text { penggerek buah kakao (C. cramerella) }\end{array}$ \\
\hline 2. & Bio Protektor 2 & Eugenol & $\begin{array}{l}\text { Keong Mas pada padi; Croccidolomia sp. } \\
\text { pada kubis; kutu } A \text {. hartiipada rimpang } \\
\text { jahe; Helopeltis sp \& penggerek buah } \\
\text { kakao }\end{array}$ \\
\hline 3. & CEES & Eugenol, Sitronelal & $\begin{array}{l}\text { Bercak daun jahe (Phyllosticta sp.); layu } \\
\text { bakteri jahe (R. solanacearum); } \\
\text { Nematoda (Meloidogyne sp.); Rayap } \\
\text { kayu kering ( } \text { C. cynocephalus); kutu daun } \\
\text { tungau Tetranychus sp. pada tanaman } \\
\text { hias; kutu } A \text {. hartii pada rimpang jahe; } \\
\text { Helopeltis sp pada kakao; penggerek } \\
\text { buah kakao (C. cramerella) }\end{array}$ \\
\hline 4. & CEKAM & Eugenol, Sinamaldehid & $\begin{array}{l}\text { Bercak daun jahe (Phyllosticta sp.); layu } \\
\text { bakteri jahe (R. solanacearum); nematoda } \\
\text { (Meloidogyne sp.); kutu } A \text {. hartii pada } \\
\text { rimpang; tungau Tetranychus sp. pada } \\
\text { tanaman hias; nyamuk demam } \\
\text { berdarah }(A \text {. aegypti) }\end{array}$ \\
\hline 5. & ASIMBO & Sitronelal Asam Salisilat & $\begin{array}{l}\text { Helopeltis sp pada kakao } \\
\text { Penggerek buah kakao (C. cramerella) }\end{array}$ \\
\hline 6. & NEEM Plus & Azadirachtin, Sitronelal & Wereng coklat pada padi \\
\hline
\end{tabular}

Sumber : Syakir, 2011

\section{Penelitian Pestisida Nabati pada Tanaman Karet}

Penyakit jamur akar putih (Rigidoporus microporus), penyakit gugur daun Corynespora (Corynespora cassiicola), penyakit gugur daun Colletotrichum (Colletotrichum gloeosporioides) dan Oidium (Oidium heveae), penyakit lapuk batang/cabang Fusarium (Fusarium sp.) serta penyakit jamur upas (Corticium salmonicolor) termasuk penyakit penting di perkebunan karet. Penyakitpenyakit ini menyerang hampir seluruh stadia pertumbuhan tanaman dan dapat mengakibatkan rendahnya produktivitas atau bahkan kematian tanaman. Sampai saat ini,teknik penanggulangan penyakit karet yangdianjurkan adalah kombinasi dari aspek kultur teknis, manipulasi lingkungan dan penggunaan pestisida, atau masing-masing aspek tersebut. Penggunaan pestisida perlu diperhatikan dengan seksama karena dampak negatifnya terhadap manusia, lingkungan, tanaman dan organisme pengganggu. Dampak negatif lainnya adalah membentuk strain baru yang tahan terhadap pestisida.

Beberapa tanaman yaitu Ageratum conyzoides, Centrosema pubescen, Emilia coccinea, Ocimum basilium, Solanum torvum (Gambar 4), Ocimum sanctum, Chromolaena odorata, Eucalyptus globules dan Carica papaya telah terbukti menghambat pertumbuhan patogen Corynespora cassiicola (Munir, 2011). 


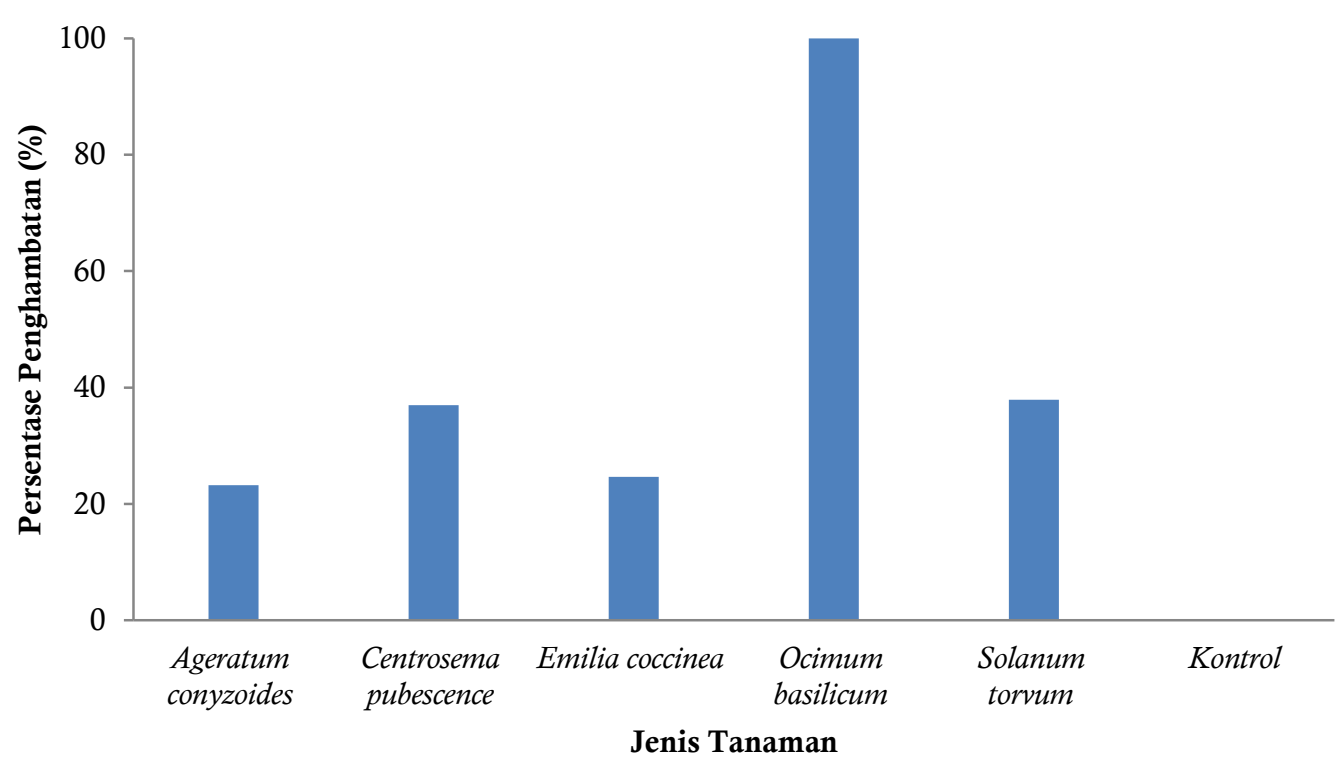

Gambar 4. Persentase penghambatan ekstrak tanaman terhadap Corynespora cassiicola Sumber: Ogbebor dan Adekunde (2005) dalam Munir (2011)

Penelitian mengenai pemanfaatan ekstrak tanaman untuk menghambat penyebab penyakit pada tanaman karet tertera pada Tabel 2. Siregar et al. (2015) melaporkan bahwa ekstrak daun bangun-bangun mempunyai aktivitas menghambat pertumbuhan koloni jamur akar putih. Santosa dan Hertiani (2005) menyatakan bahwa senyawa utama yang terkandung dalam daun bangun-bangun adalah polifenol, saponin, glikosida, flavonoid dan minyakatsiri. Senyawa polifenol secara umum berkhasiat sebagai antimikroba dan antioksidan. Ekstrak alkohol daun bangunbangun bersifat anti bakteri terhadap bakteri patogen usus. Duke (2000) juga melaporkan khasiat daun bangun-bangun sebagai antilitiolitik, kemoprotektif dan bersifat sebagai antioksidan.
Ekstrak gatubrotemsi (gadung, akar tuba, brotowali, daun tembakau dan sirih) yang terdiri dari campuran ekstrak bahan tanaman tersebut merupakan salah satu pestisida nabati yang manjur mengendalikan penyakitpenyakit di pembibitan tanaman perkebunan khususnya bercak daun pada tanaman kelapa sawit dan bercak daun Colletotricum sp. pada tanaman karet (Sugiyanto, 2013). Pada tanaman hortikultura, ekstrak gadung dan tembakau berfungsi sebagai insektisida alami dan menangkal Epilachna sparsa (Hasanah et al., 2012; Santi, 2010), ekstrak daun sirih mampu menekan pertumbuhan Colletotricum capsici (Nurhayati, 2007), dan ekstrak brotowali dapat mengendalikan Spodoptera litura (Septian et al., 2013). Bahan aktif dari gatubrotemsi adalah sebagai berikut (Sugiyanto, 2013): 
Tabel 2. Penelitian ekstrak tanaman untuk menghambat penyebab penyakit pada tanaman karet

\begin{tabular}{|c|c|c|c|c|}
\hline No & Ekstrak tanaman & Senyawa Aktif & OPT Target & Referensi \\
\hline 1. & $\begin{array}{l}\text { Daun kemangi (Ocimum } \\
\text { sanctum L.) }\end{array}$ & $\begin{array}{l}\text { Alkaloid, } \\
\text { terpenoid }\end{array}$ & $\begin{array}{l}\text { Corynespora } \\
\text { cassiicola }\end{array}$ & Muniret al., 2008 \\
\hline 2. & $\begin{array}{l}\text { Daun bangun-bangun } \\
\text { (Coleus amboinicus) }\end{array}$ & $\begin{array}{l}\text { Flavanoid, } \\
\text { saponin, steroid, } \\
\text { polifenol. }\end{array}$ & $\begin{array}{l}\text { Rigidoporus } \\
\text { microporus }\end{array}$ & Siregar et al., 2015 \\
\hline 3. & $\begin{array}{l}\text { Ekstrak kunyit (Curcuma } \\
\text { domestica) }\end{array}$ & $\begin{array}{l}\text { Atsiri, curcumin, } \\
\text { tannin, resin }\end{array}$ & $\begin{array}{l}\text { Rigidoporus } \\
\text { microporus }\end{array}$ & $\begin{array}{l}\text { Kusdiana et al., } \\
2016\end{array}$ \\
\hline 4. & $\begin{array}{l}\text { Daun Myracrodruon } \\
\text { urundeuva, Lafoensia pacari } \\
\text { dan Caryocar brasiliense }\end{array}$ & $\begin{array}{l}\text { Polifenol, } \\
\text { alkaloid }\end{array}$ & $\begin{array}{l}\text { Colletotrichum } \\
\text { gloeosporioides dan } \\
\text { C. Cassiicola }\end{array}$ & $\begin{array}{l}\text { Naruzawa dan } \\
\text { Papa, } 2011\end{array}$ \\
\hline 5. & Plumeria alba & $\begin{array}{l}\alpha \text {-amyrin dan } \\
\text { asam } \\
\text { heksadekanoat }\end{array}$ & C. gleosporoides & Nor et al., 2014 \\
\hline 6. & Peganum harmala & Alkaloid & C. cassiicola & $\begin{array}{l}\text { Razzaghi-Abyaneh, } \\
2013\end{array}$ \\
\hline 7. & Achillea millefolium & Nerolidol & C. cassiicola & $\begin{array}{l}\text { Carlos et al., 2010; } \\
\text { Chan et al., } 2016\end{array}$ \\
\hline 8. & $\begin{array}{l}\text { Olea cuspidata, Cymbopogon } \\
\text { citratus \& Brassica juncea }\end{array}$ & Isothiosianat & $\begin{array}{l}\text { Corticium } \\
\text { salmonicolor }\end{array}$ & Prashad et al., 2014 \\
\hline
\end{tabular}

1. Umbi gadung (Dioscorea composita): mengandung saponin, amilum, $\mathrm{CaC}_{2} \mathrm{O}_{4}$, antidotum, besi, kalsium, lemak, garam fosfat, protein, dan vitamin. Komponen penting pada gadung yaitu zat beracun asam sianida $(\mathrm{HCN})$.

2. Akar tuba (Deris sp): senyawa yang telah ditemukan antara lain adalah rotenon (diekstrak menggunakan eter/aseton dan menghasilkan $2-4 \%$ resin rotenon). Rotenon bekerja sebagai racun sel yang sangat kuat. Kematian OPT terjadi beberapa jam sampai beberapa hari setelah terkena rotenon. Ekstrak akar tuba juga memiliki sifat insektisida untuk mengendalikan Nesiodiocoris tenuis yang menyerang tanaman tomat (Rante et al., 2013).

3. Brotowali (Tinospora $s p$ ): bersifat fungistatik terhadap jamur dan mengandung senyawa berberin yang berkhasiat menghambat pertumbuhan bakteri.

4. Tembakau (Nicotiana tobacum): Senyawa yang dikandung adalah nikotin. Nikotin ini tidak hanya racun untuk manusia, tetapi juga dapat dimanfaatkan untuk racun serangga. Daun tembakau kering mengandung $2-8 \%$ nikotin. Nikotin merupakan racun syaraf yang bereaksi cepat dan berperan sebagai racun kontak bagi serangga (ulat perusak daun, aphids, triphs)dan pengendali jamur (fungisida).

5. Sirih (Piper bettle): Minyak atsiri dari daun sirih mengandung minyak terbang, seskuiterpen, pati, diatase, gula, zat samak dan kavikol yang memiliki daya mematikan kuman, antioksidasi dan fungisida anti jamur. Kandungan bahan aktif fenol dan kavikol daun sirih hutan juga dapat dimanfaatkan sebagai pestisida nabatiuntuk mengendalikan hama penghisap daun.

Colletotrichum gleosporoides, penyebab penyakit gugur daun Colletotrichum pada tanaman karet, juga menyerang tanaman lain diantaranya tanaman jambu biji dan pepaya. Ekstrak daun dan batang tanaman Kamboja Putih (Plumeria alba), famili 
Apocynaceae dilaporkan mampu menghambat perkembangan Colletotrichum gleosporoides pada jambu biji (Psidium guajava) secara in vitro dan in vivo masing-masing dengan konsentrasi $11 \mu \mathrm{L}$ (ekstrak cair) dan 32 g/L (Nor et al., 2014). Sebagian besar tanaman famili Apocynaceae yaitu Rhazyastricta, Aspidosperma pachypterum, Allamanda blanchetti dan Picralima nitida dilaporkan mempunyai aktivitas antimikroba yang cukup kuat. Haron et al. (2013) melaporkan bahwa ekstrak kloroform dari beberapa spesies tanaman Allamanda mempunyai aktivitas kuat menghambat pertumbuhan miselia $C$. gleosporoides pada tanaman pepaya. Aktivitas penghambatannya sebesar $100 \%$ pada konsentrasi $5 \mathrm{mg} / \mathrm{ml}$, lebih kuat dibandingkan aktivitas penghambatan dari ekstrak biji jarak pagar (Jatropha curcas) sebesar 78,87\% pada konsentrasi $10 \mathrm{mg} / \mathrm{ml}$ (Rahman et al., 2011; Haron et al., 2013). Beberapa senyawa utama yang terkandung dalam tanaman Allamanda adalah campesterol, sitosterol, plumericin, squalen dan tokoferol, sedangkan senyawa yang terkandung dalam J. curcas antara lain adalah asam heksadekanoat, asam oktadekanoat dan turunannya (Haron et al., 2013; Rahman et al., 2014). Ekstrak etanol dari Lantana camara juga menunjukkan penghambatan yang signifikan terhadap $C$. gleosporoides pada percobaan di laboratorium (Prasad dan Anamika, 2015).

\section{Kesimpulan}

Dengan kekayaan plasma nutfah Indonesia, jenis metabolit sekunder tanaman juga sangat beragam dan melimpah. Tanaman yang mengandung senyawa dari golongan flavanoid, alkaloid, dan terpenoid dapat menjadi alternatif pengendalian penyakit tanaman karet. Beberapa ekstrak tanaman yang telah diteliti sebagai pengendali OPT tanaman karet adalah bangun-bangun, kemangi dan kunyit. Penelitian pemanfaatan ekstrak tanaman sebagai pestisida nabati pengendali penyakit tanaman karet perlu dilanjutkan. Fokus penelitian antara lain adalah eksplorasi dan pendataan pestisida nabati yang potensial, isolasi dan pemurnian bahan aktif, studi mekanisme kerja, serta optimasi sinerginya dengan pestisida lain.

\section{Daftar Pustaka}

Ahmad, A., Kaleem, M., Ahmed, Z., and Shafiq, H.(2015). Therapeutic potential of flavonoids and their mechanism of action against microbial and viral infections-A review. Food Research International, 77(2), 221-235.

Anurag, K., Irchaiya, R., Yadaf, A., Gupta, N., Kumar, S., Prakash, A., and Gurjar, H. (2015). Metabolites in plants and its classification. World Journal of Pharmacy and Pharmaceutical Sciences, 4(1), 287-305.

Bohlmann, J., andKeeling, C.I. (2008). Terpenoid biomaterials. The Plant Journal, 54, 656-669.

Carlos,M.M., Schwan-Estrada, K.R.F., Itako, A.T., Bonaldo,S.M.,Mesquini,R.M., Carv alho, J.B., and Stangarlin, J.R. (2010). Effect of crude extract and essential oil of Achillea millefolirum $L$. on the in vitro development of C. cassiicola and protection of cucumber against corynespora leaf spot. Arquivos do Instituto Biológico, 77(2), 309-316.

Cavoski, I., Caboni, P., and Miano, T. (2011). Natural pesticides and future perspectives. InMargarita Stoytcheva (Eds.), Pesticides in the Modern World Pesticides Use and Management, (pp. 169190). Rijeka : InTech Europe.

Chan, W., Tan, L.T., Chan, K., Lee, L., and Goh, B.(2016). Nerolidol: A Sesquiterpene Alcoholwith Multi-Faceted Pharmacological and Biological Activities. Molecules, 21(529), 1-40.

Dewick, P.M. (2009). Medicinal Natural Products: A Biosynthetic Approach, 3rd Edition. West Sussex, UK: John Wiley \& Sons, Ltd. 
Direktorat Jendral Prasarana dan Sarana Pertanian. (2014). Pestisida Pertanian dan Kehutanan Terdaftar 2014. Jakarta: Direktorat Jenderal Prasarana dan Sarana Pertanian.

Duke, A.(2000). Constituens and Ethnobotanical Databases. Phytochemical database, USDA-ARS-NGRL.Retrieved fromhttp://www.ars-grin.gov/cgibin/duke/farmacy-scroll3.pl.

European Food Safety Authority. (2013). Conclusion on the peer review of the pesticide risk assessment of the active substance plant oils/rapeseed oil. European Food Safety Authority Journal, 11(1), 3058. [45 pp.]

European Food Safety Authority. (2014). Outcome of the consultation with Member States and EFSA on the basic substance application for lecithins for use in plant protection as a fungicide on vineyards, fruit trees, vegetables and ornamentals. EFSA supporting publication 2014:EN-643. 34 pp.

Geetha, R.V., and Roy, A. (2014). Essential Oil Repellents- A short Review. International Journal Drug Development and Research, 6(2), 20-27.

Gleason, F and Chollet, R. (2012). Plant Biochemistry. Massachusetts: Jones \& Bartlett Learning.

Haron, F.F., Sijam, K.,Omar, D., and Rahmani, M. (2013). Chemical composition and screening for antifungal activity of Allamanda spp. (Apocynaceae) crude extracts against Colletotrichum gloeosporioides, causal agent of anthracnose in papaya. Australian Journal of Basic and Applied Sciences, 7(1), 88-96.

Hasanah, M., Tangkas, I.M., danSakung, J.(2012). Daya insektisida alami kombinasi perasan umbi gadung dan ekstrak tembakau. Jurnal Akademika Kimia, 1(4), 166-173.
Herrmann, K.M. and Weaver, L.M. (1999). The Shikimate Pathway. Annual Reviewof Plant Physiology and Plant Molecular Biology, 50, 473-503.

Isman, M.B., (2006) Botanical insecticides, deterrents, and repellents in modern agriculture and an increasingly regulated world, Annual Review of Entomology, 51, 4566.

Kabera, J.N., Semana, E., Mussa, A.R., and He, X.(2014). Plant Secondary Metabolites: Biosynthesis, Classification, Function and Pharmacological Properties. Journal of Pharmacy and Pharmacology, 2, 377-392.

Kongkaew, C., Sakunrag, I., Chaiyakunapruk, N., and Tawatsin, A. (2011). Effectiveness of citronella in preventing mosquito bites. Tropical Medicine and International Health,16(7), 802-810.

Kusdiana, A.P.J., Munir, M., dan Suryaningtyas, H. (2016). Studi pemanfaatan ekstrak kunyit (Curcuma domestica Valeton) untuk pengendalian penyakit jamur akar putih pada tanaman karet. Warta Perkaretan, 35(1), 25-36.

Lee, S.T., Welch, K.D., Panter, K.E., Gardner, D.R., Garrossian, M., and Chang, C.T. (2014). Cyclopamine: From Cyclops Lambs to Cancer Treatment. Journal Agriculture and Food Chemistry, 62(30),7355-7362.

Mariska, I. (13 Agustus 2013). Metabolit Sekunder: Jalur pembentukan dan kegunaannya. Balai Besar Penelitian Bioteknologi dan Sumberdaya Genetik. Diakses dari http://biogen.litbang.pertanian.go.id/

Munir, M. (2011). Potensi dan pemanfaatan bahan nabati untuk pengendalian penyakit gugur daun Corynespora dan Colletotrichum pada tanaman karet. Warta Perkaretan, 30(1), 18-25. 
Munir, M., Purwoko, T., dan Pawirosoemardjo, S. (2008). Potensi penghambatan ekstrak daun kemangi (Ocimum sanctum L.) terhadap pertumbuhan Corynespora cassiicola penyebab penyakit gugur daun pada tanaman karet (Hevea brasiliensis Muell. Arg.). Prosiding Seminar Nasional Pengelolaan Organisme Pengganggu Tumbuhan dan Sumber Hayati yang berwawasan lingkungan dalam menyikapi dampak Pemanasan Global. Palembang, Oktober 2008.

Naruzawa, E.S., and Papa, M.F.S. (2011). Antifungal activity of extracts from Brazilian Cerrado plants on Colletotrichum gloeosporioidesand Corynespora cassiicola. Revista Brasiliera de Plantas Medicinais, 13(4), 408-412.

Nes, W.D. andZhou, W.(2001). Terpenoids: Higher. Encyclopedia of Life Sciences. Nature Publishing Group. Retrieved from http://rubisco.ugr.es

Nor, M.M., Hassan, H.H.M., Ravi, N.H.N.M., and Omar, M.N. (2014). Effect of Plumeria alba's bioactive extract against Colletotrichum gleosporoides in Vitro and in Vivo. Journal of Agricultural Science and Technology,4(3B), 195-199.

Nurhayati. (2007). Pertumbuhan Colletotrichum capsici penyebab antraknosa buah cabai pada berbagai media yang mengandung ekstrak tanaman. Jurnal Rafflesia, 9(1), 32-35.

Ogbebor, N., and Adekunle, A.T. (2005). Inhibition of conidial germination and mycelial growth of Corynespora cassiicola (Berk \& Curt.) of rubber (Hevea brasiliensis Muell. Arg.) using extracts of swome plants. Africans Journal of Biotechnology, 4(9), 996-1000.

Prashad, D., Ram, V., Sharma, I., and Sharma, S. (2014). Compatibility of native potential antagonists with fungicides and essential oils against Corticium Salmonicolor. The Bioscan, 9(1), 417-423.
Prasad, R.R., and Anamika. (2015). Effects of plant leaf extract against Colletotrichum gleosporoides causing post-harvest disease of papaya. Journal of Agricultural Science, 7(5), 195-198.

Psota, V., Ouředníčková, J., andFalta, V.(2010). Control of Hoplocampa testudinea using the extract from Quassia amara in organic apple growing. Horticultural Science, 37(4), 139-144.

Rahman, M., Ahmad, S.H., Mahmud, T.M.M., and Mohamad, Z.A.R.(2011). Extraction of Jatropha curcas fruits for antifungal activity against anthracnose (Collethotrichum gloeosporioides) of papaya. African Journal of Biotechnology, 10, 9796-9799.

Rahman, M., Ahmad, S.H., Mohamed, M.T.,and Abdurrahman, M.Z. (2014). Antimicrobial compounds from leaf extracts of Jatropha curcas, Psidium guajava, and Andrographis paniculata. The Scientific World Journal, 2014, 1-8.

Rante, C.S., Sembel, D.T., Meray, E.R.M., Ratulangi, M.M., Dien, M.F., and Kandowangko, D.S. (2013). Penggunaan insektisida botanis untuk mengendalikan hama pada tanaman tomat. Eugenia, 19(2), 97-102.

Razzaghi-Abyaneh, M.,Shams-Ghahfarokhi, M., and Rai, M. (2013). Antifungal Metabolites from Plants. Berlin: SpringerVerlag. Retrieved from http://www.springer.com/978-3-64238075-4

Santi, S.R. (2010). Senyawa aktif antimakan dari umbi gadung. Jurnal Kimia, 4(1), 7178.

Santosa, M. dan Hertiana, T. (2005).Kandungan senyawa kimia dan efek ekstrak air daun bangun-bangun (Coleus amboinicus, L.) pada aktivitas fagositosis netrofil tikus putih (Rattus norvegicus). Majalah Farmasi Indonesia, 16(3), 141-148. 
Septian, R.E., Isnawati.,danRatnasari, E (2013). Pengaruh kombinasi ekstrak biji mahoni dan batang brotowali terhadap mortalitas dan aktivitas makan Ulat Grayak pada tanaman cabai rawit. Lentera Bio, 2(1), 107-112.

Siregar, T.H.S., Dalimunthe, C.I., Sembiring, Y.R.V., Andriyanto, M.,Darwin, H.S., dan Barus, D.A. (2015). Identifikasi dan uji antagonis metabolit sekunder bangunbangun (Coleus amboinicus) sebagai fungisida nabati untuk mengendalikan penyakit jamur akar putih (Rigidoporus microporus). Laporan akhir KKP3N 2015. Deli Serdang. Balai Penelitian Sungei Putih.

Sugiyanto. (2013). Ekstrak Gatubrotemsi manjur untuk penyakit tanaman perkebunan.Diakses dari http:// ditjenbun.pertanian.go.id/perlindungan/b erita184ekstrakgatubrotemsimanjuruntukp enyakittanamanperkebunan.html
Supriadi. (2013). Optimasi pemanfaatan berbagai jenis pestisida untuk mengendalikan hama dan penyakit tanaman. Jurnal Penelitian dan Pengembangan Pertanian, 32(1), 1-9.

Syakir, M. (2011). Status penelitian pestisida nabati Pusat Penelitian dan Pengembangan Tanaman Perkebunan. Seminar Nasional Pestisida Nabati IV, Jakarta, Okotober 2011.

Ting, Z., Chang-Hong, W., and Zheng-Tao, W. (2010). Chemical constituents and pharmacological actions of genus Peganum: research advences. Journal of International Pharmaceutical Research,37(5), 333-45.

Yoon, M.Y., Cha, B., and Kim, J.C. (2013). Recent trends in studies on botanical fungisides in agriculture. Korean Society of Plant Pathology; The Plant Pathology Journal, 29(1), 1-9. 